DRAGO PUPAVAC, Ph.D. ${ }^{1}$

E-mail: drago.pupavac@veleri.hr

ROBERT MARŠANIĆ, Ph.D. ${ }^{2}$

E-mail: robert.marsanic1@gmail.com

LJUDEVIT KRPAN, Ph.D. ${ }^{3}$

E-mail: ljudevit.krpan@pgz.hr

${ }^{1}$ Polytechnic of Rijeka

Vukovarska 58, 51000 Rijeka, Croatia

${ }^{2}$ Road Administration Primorje-Gorski Kotar County

Nikole Tesle 9, Rijeka 51000, Croatia

${ }^{3}$ Primorje-Gorski kotar County

Administrative Department for Regional Development

Infrastructure and Project Management

Adamićeva 10, Rijeka 51 000, Croatia
Transport Logistics Original Scientific Paper Submitted: 22 June 2020 Accepted: 6 Oct. 2020

\title{
OPTIMIZATION OF COVID-19-FREE SUPPLY CHAINS
}

\section{ABSTRACT}

The basic aim of this paper is to research the importance of supply chain optimization in the circumstances of the COVID-19 crisis. The research object is the optimum selection of active participants before and after the COVID-19 crisis. The initial hypothesis of this paper is that optimal COVID-19-free supply chains can be formed with a dynamic programming method, the costs of which will be higher than those when this restriction would not exist, but significantly lower than those formed if the optimization principle in the selection of supply chain stakeholders would be neglected. Research results in this scientific discussion paper are based on the analysis and synthesis method, comparative method, and dynamic programming method. The main findings of this paper point to the conclusion that the COVID-19 crisis affected the reduction of goods flow within supply chains, reduction of potential participants in supply chains, reduction of supply chains business safety, and increase in business costs.

\section{KEYWORDS}

supply chain; COVID-19; dynamic programming; optimization.

\section{INTRODUCTION}

COVID-19 has fundamentally changed the social and economic life of the world. Since this new coronavirus was first identified at the end of 2019 in Wuhan, the capital of the Hubei province in Central China, more than 5 million people have been infected in 213 countries and territories, leading to over 333446 deaths [1]. In 2020, the world economy may see a $-1 \%$ decrease instead of the foreseen $2.5 \%$ increase [2]. According to some evaluations, the world economy decline may amount up to $2 \%$, and in the conditions of the extended pandemic even up to 4\% [3]. Countries that are exceptionally dependent on tourism and export of trade and services will be stricken the most. Therefore, according to some evaluations, in 2020 [4] the Spanish economy will see a $15.5 \%$ decline, the Croatian economy a $9.4 \%$ decline [5], and the Italian economy an $8 \%$ decline. As businesses lose income, unemployment will most probably increase, thus changing the supply-side shock for the economy to demand-side shock [6]. Questions arising in the whole business world that should be given scientifically based answers are the following: how to ensure survival in the market and gain as much profit as possible in business conditions changed by the COVID-19? Could COVID-19 be the "black swan" event [7] that forces many companies to rethink and transform their global supply chain model from traditional linear supply chain model into a digital supply network? How to provide full visibility within the logistic chain and its ability to respond to shocks on both the supply and demand side? Can protectionist measures result in returning to traditional supply chain models? How to make a supply chain shorter? How to provide full cooperation within a supply chain? How to increase supply chain flexibility? Should a supply chain be based on a larger or smaller number of stakeholders? How to choose active supply chain stakeholders? How to optimize a supply chain?

A scientific hypothesis was defined closely connected to the current questions asked: optimal COVID-19-free supply chains can be formed with the dynamic programming method, the costs of which will be higher than those when this restriction 
would not exist, and significantly lower than those that would form if the optimization principle in the selection of supply chain stakeholders was neglected, i.e., under protectionist measures.

To find answers to the questions asked and to corroborate the defined hypothesis, the research results in this paper are based on the dynamic programming method. Its basis lies with Bellman's (1954) principle of optimality that can be expressed in the following way: "An optimal policy has the property that whatever the initial state and initial decisions are, the remaining decisions must constitute an optimal policy with regard to the state resulting from the first decisions" [8]. The basic feature of dynamic programming methods [9] is reflected in the fact that there are no universal methods and their corresponding algorithms for applying dynamic programming. Specifically, solving almost every practical problem by applying the dynamic programming method requires a particular and special approach. Likewise, solution to any undertaking of a supply chain requires a particular and special approach.

\section{THEORETICAL FRAMEWORK AND RESEARCH PROBLEM}

Coronaviruses are a large family of viruses. Coronavirus disease 2019 (COVID-19) is caused by the SARS-CoV-2 virus, which is a new virus in humans causing respiratory illness that can be spread from person-to-person. The COVID-19 pandemic is first and foremost a serious threat to global health, but also a social and economic threat. Because of that, the entire world has the same goal: to beat
COVID-19. COVID-19 took the world by surprise and completely unexpectedly became a global problem (Figure 1).

When COVID-19 began to take its toll in China, a worldwide shock arose on the supply side due to a reduced possibility of available goods procured in China, which was either about final products, semi-products, or parts of products. And while numerous supply chains tried to adjust to a newly developed situation (to define what production is, to what extent it is feasible, and what demands should be met), a new negative shock occurred on the supply side caused by closing national borders, shutdowns or factories working at reduced capacity, all of which resulted in the decrease of total output. The impact of the supply shock on business conditions is shown in Figure 2.

The reduction of aggregate supply was followed by the output reduction and price increase tendency, which prompted many to plead for protectionist measures and revival of uncompetitive domestic production. In order to prevent uncompetitive market behavior and unjustified price increase, the governments opted for strict controls and controlling prices for numerous products during the COVID-19 pandemic. Companies may violate competition rules if the price reaches an unfair level or if the price increase is coordinated with other companies. Price increase of products such as face masks and disinfectants, but also of many other products related to preventing the spread of COVID-19, was a particular cause for concern.

The supply-side shock was firstly followed by a positive demand-side shock where buyers tried to stock as many products as possible and where in one day only they did shopping in the value of the

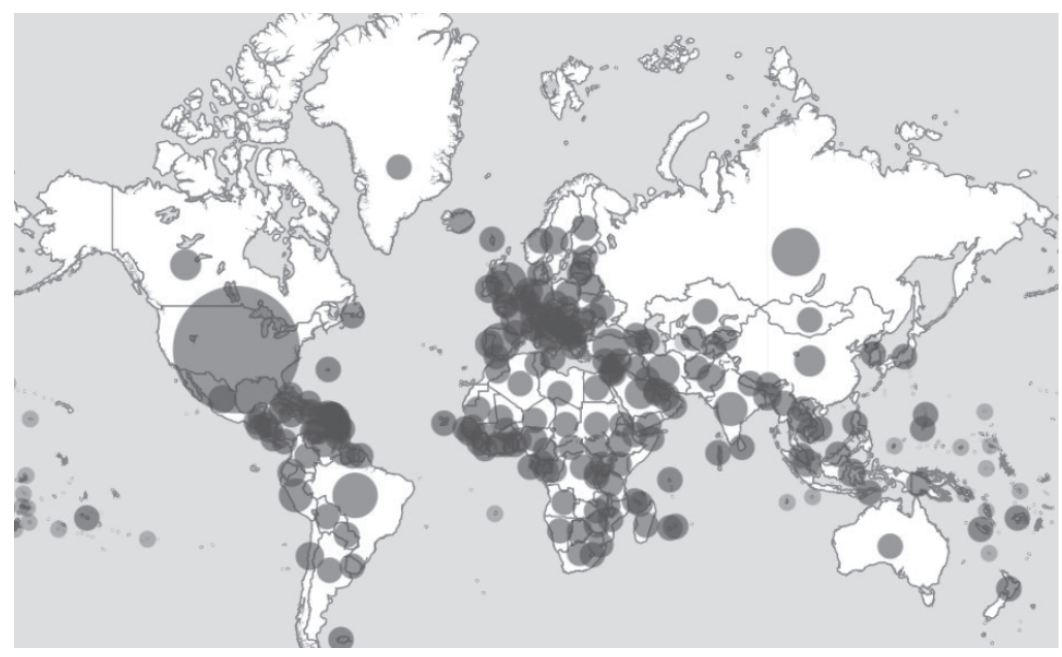

Figure 1-Confirmed COVID-19 cases until 23 May 2020 [1] 


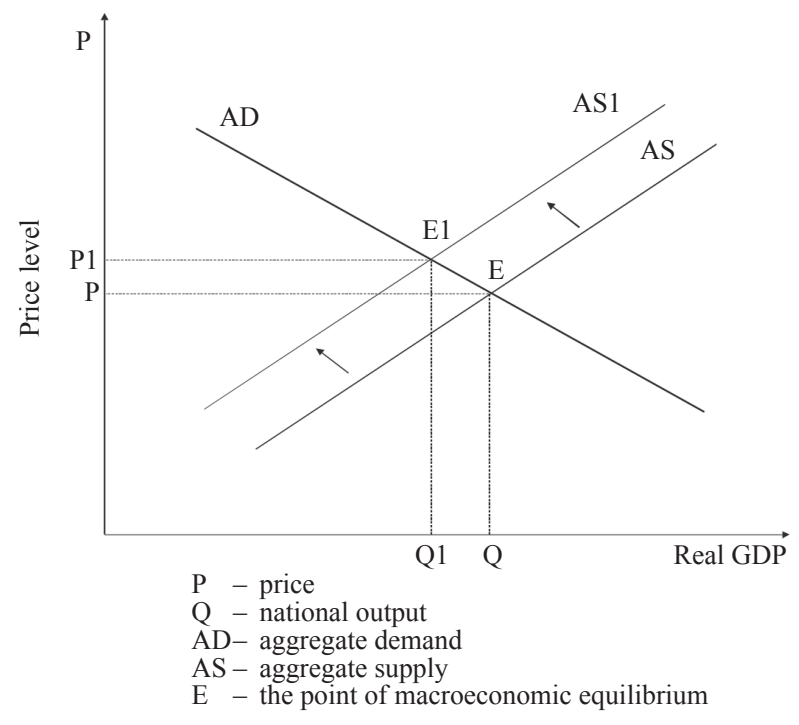

Figure 2 - Supply shock recession

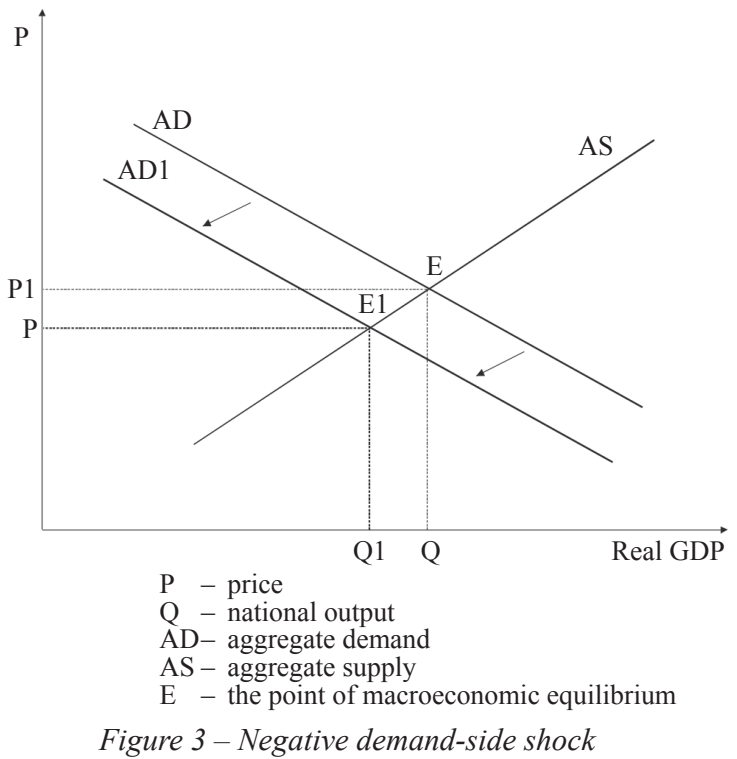

total monthly consumption. Fear gripped buyers that supply chains, particularly those in the food section, would not be able to respond to the enormous demand increase. Under a sudden shock in market demand [10], the number of nodes and the number of active and fully cooperative stakeholders within the supply chain affected the supply chain performance. This demand-side shock threatened with the occurrence of the "Bullwhip Effect" in supply chains, i.e., with errors in the forecast and quantity of orders [11]. A typical example for this was toilet paper whose consumption is otherwise very stable and easily predictable.

Shortly afterwards a new, this time negative shock followed on the demand side caused by curfew measures, which, along with uncertainty, created output reduction, unemployment increase, and reduced income - a fatal spiral of a long-term economic crisis that will largely outlive the very Corona crisis. The negative demand-side shock is shown in Figure 3.

A sudden drop in demand results in a shift in the demand curve to the left. Negative demand shock results in the destruction of production. Production surplus ends up in inventories, the number of employees decreases, and thus the level of production decreases, too. The vicious cycle of poverty is under way [12].

\section{DATA AND METHODOLOGY}

To clearly present the effects of COVID-19 on supply chains optimization, this paper analyses a particular practical example of the supply chain. Supply chain is a network that consists of four entities: suppliers, distribution networks, manufacturers, and customers [13]. Supply chains have different numbers of nodes, different numbers of active participants, different types of connections and influences on each other including transportation, information sharing, and financial flows [14]. Supply chains should be flexible, quick enough, dependable, and cost-efficient. Coordination and collaboration in different activities are essential for the success of the supply chain [15]. Production-distribution networks include both the supply chain configuration and the related operational decisions. The main goal is to achieve the best trade-off between costs and customer service level [16].

Let's say that for a product to be manufactured and delivered on the demand location within the logistic chain, certain production and logistic activities need to be done, which can be classified into five phases (I-V): $x_{1}$ (procurement of raw materials), $x_{2}$ (production), $x_{3}$ (warehousing), $x_{4}$, (transport), $x_{5}$ (selling), and for which within the global logistic system it is possible to engage 23 different participants: $f_{1}, f_{2}, f_{3}, \ldots f_{23}$. A logistic operator is familiar with the engagement schedule of participants within the logistic chain in carrying out single phases of the logistic undertaking (cf. Table 1).

Data from the bottom of Table 1 show that some participants can be engaged in carrying out two or three supply chain phases. For example, it is evident that the participant $\mathrm{f} 16$ from Austria can be engaged to execute phase one and two, i.e., for the delivery of raw materials and production. Table 1 also contains information on costs for carrying out certain 
Pupavac D, Maršanić R, Krpan Lj. Optimization of COVID-19-Free Supply Chains

Table 1 - Production phases within the supply chain and potential supply chain participants

\begin{tabular}{|c|c|c|}
\hline Phases of the logistic process & $\begin{array}{l}\text { Potential supply chain participants and } \\
\text { COVID-19 risk }\end{array}$ & $\begin{array}{l}\text { Costs of each phase within the } \\
\text { supply chain (in } 000 € \text { ) }\end{array}$ \\
\hline $\begin{array}{l}\text { I. Delivery of raw materials Incoterms } \\
\text { EXW - Ex Works }\end{array}$ & $\begin{array}{l}f_{1}-\text { Russia, HR } \\
f_{2}-\text { Turkey, LR } \\
f_{3}-\text { Algeria, NR } \\
\end{array}$ & $\begin{array}{l}16 \\
10 \\
12\end{array}$ \\
\hline II. Production & $\begin{array}{l}f_{4}-\text { Czech, LR } \\
f_{5}-\text { Hungary, NR } \\
f_{6}-\text { Poland, LR } \\
f_{7}-\text { Slovakia, LR }\end{array}$ & $\begin{array}{l}20 \\
28 \\
16 \\
24\end{array}$ \\
\hline $\begin{array}{l}\text { III. Land carriage (railway operator, road } \\
\text { transport operator) }\end{array}$ & $\begin{array}{l}f_{8}-\mathrm{DB} \text { national railway operator, NR } \\
f_{9}-\mathrm{ABX} \text { Logistics, NR }\end{array}$ & $\begin{array}{l}4 \\
6\end{array}$ \\
\hline IV. Sea shipping (ship operators) & $\begin{array}{l}f_{10}-\text { Global Alliance, NR } \\
f_{11} \text { - Grand Alliance, NR } \\
f_{12}-\text { Maersk-Sealand, NR }\end{array}$ & $\begin{array}{l}6 \\
5 \\
7\end{array}$ \\
\hline $\begin{array}{l}\text { V. Distribution (distributors in North } \\
\text { America) }\end{array}$ & $\begin{array}{l}f_{13}-\text { East Coast, HR } \\
f_{14}-\text { West Coast, LR } \\
f_{15}-\text { Canada, NR } \\
\end{array}$ & $\begin{array}{c}9 \\
8 \\
11\end{array}$ \\
\hline I, II & $f_{16}-$ Austria, HR & 20 \\
\hline II, III & $f_{17}-$ Switzerland, LR & 24 \\
\hline I, II, III & $f_{18}-\mathrm{GB}, \mathrm{HR}$ & 40 \\
\hline II, III, IV & $f_{19}-$ Croatia, NR & 36 \\
\hline III, IV, V & $f_{20}-$ Germany, NR & 48 \\
\hline III, IV & $f_{21}-$ Italy, HR & 30 \\
\hline $\mathrm{IV}, \mathrm{V}$ & $\begin{array}{l}f_{22}-\text { USA, HR } \\
f_{23}-\text { USA, LR }\end{array}$ & $\begin{array}{l}26 \\
32 \\
\end{array}$ \\
\hline
\end{tabular}

logistic activities and on danger of compromising the supply chain with COVID-19 (HR - High Risk, LR - Low Risk, NR - No Risk).

\section{MATHEMATICAL MODEL}

It is possible to present the described production process within the supply chain by means of mathematical relations in the following way: $x_{i f j}=1, i=1,2, \ldots, n ; j=1,2, \ldots, m$ if services of a potential logistic chain participant $f_{j}$ are used in the production phase within the global logistic chain $x_{i}$.

$$
\begin{aligned}
& \left(\sum_{i=1}^{k-(r-1)} x_{i+r-1}\right) f_{j}=k-(r-1) \\
& k \in[1, n], r \in[1, n] k>r, j=1,2, \ldots, m
\end{aligned}
$$

if services of a potential logistic participant $f_{j}$ are used in the $k-(r-1)$ of the production phases within the global logistic chain and specifically from $r$, including production phases $r$ and $k$. $x_{i f j}=0, i=1,2, \ldots, n ; j=1,2, \ldots, m$ if services of a potential logistic participant $f_{j}$ are not used for the production phase $x_{i}$.

Except for the aforementioned, the following requirements arising from the very nature of the problem should be borne in mind: $\sum_{i=1}^{n}\left(x_{i}=n\right)$ which means that the selected logistic production process within the global logistic chain has to be complete, i.e., it has to comprise all $n$ phases.

$f_{j}=1, j=1,2, \ldots, m$, if services of a potential global logistic chain participant $f_{j}$ are used in the selected logistic process, and

$f_{j}=0, j=1,2, \ldots, m$, if services of a potential global logistic chain participant $f_{j}$ are not used in the selected logistic process.

Based on the data from Table 1, it is evident that some of the potential global logistic chain stakeholders might be engaged in several production phases within the logistic chain. Such conditions can be defined with the pair $\left(x_{i}, f_{j}\right), i=1,2, \ldots, n$; $i=1,2, \ldots, i$, which means that with this pair it can be defined whether during a single phase of the 
execution of the logistic process a potential participant $f_{j}$ will be engaged, or if their engagement is not possible in the given phase. If the potential logistic chain participants $f_{j}, j=1,2, \ldots, i$ are allocated to every phase of carrying out the logistic process $x_{i}, i=1,2, \ldots, n$, all possible conditions of the services production within the logistic chain will be obtained that can be marked with $L$.

Now the optimal selection of participants can be set in the following way: from all $\mathrm{m}$ possible (potential) supply chain participants, those meeting all requested requirements are to be selected so that the criterion function

$z^{*}=\sum_{\left(x_{i}, f i\right) \in L} c\left(x_{i}, f_{i}\right)$

with restrictions:

$$
\begin{aligned}
& x_{i f}<1, i=1,2, \ldots, n, j=1,2 \ldots, m \\
& \left(\sum_{i=1}^{k-(r-1)} x_{i+r-1}\right) f_{j} \leq k-(r-1) \\
& k \in[1, n], k>r, j=1,2, \ldots, m \\
& \sum_{i=1}^{n} x_{i}=n \\
& f_{j}=\left\{\begin{array}{ll}
0 \\
1
\end{array}\right]=1,2, \ldots, m
\end{aligned}
$$

assumes the maximum or minimum value. The following can be taken for the criterion function: production costs within the logistic chain, time needed for executing production within the logistic chain, engagement of capacities needed for executing production within the logistic chain, engagement of people needed for production within the logistic chain (...).

Taking into account specific features of logistic processes, and in order to bring the goods to the delivery point by appropriate transport means without unnecessary retentions and execution of additional logistic activities, it seems appropriate to describe the logistic process with the oriented network. Such networks are quite suitable for modelling practical logistic problems where solving the problem comes down to defining an extreme (shortest or longest) way.

For defining the shortest way between two nodes, for example 1 and $n$, in the oriented network $G=N, L)$, whose set of nodes $N=\{1,2, \ldots, n\}$ and branches $(i, j) \in L$, where $i<j$, based on the optimality principle, the following recursive equation can be formed:

$f(j)=\min _{i}\left\{f(i)+c_{i j}\right\} \quad j=2,3, \ldots, n$

whereby $f(1)=0$

\section{RESEARCH RESULTS AND DISCUSSION}

In order to approach the optimization of selecting active participants within a supply chain, it is necessary to design two appropriate supply chain networks. The first network refers to carrying out a logistic undertaking prior to the COVID-19 crisis breakout, and the other one to carrying out a logistic undertaking in the circumstances of the COVID-19 crisis. Before an appropriate supply chain network is designed, it is important to bear in mind that it is not necessary to take into consideration all potential supply chain participants. In the first step, it is necessary to eliminate all potential participants that do not contribute to carrying out the logistic undertaking in accordance with the aim function. These are potential participants that required bigger costs for carrying out certain activities within the logistic chain under the conditions before the outbreak of the COVID-19 crisis, and did not guarantee COVID-19-free supply chains under the conditions after the breakout of the COVID-19 crisis.

For example, in the first phase of the logistic chain for raw materials supply, it is possible to engage three potential suppliers, specifically: $f_{1}$ from Russia, $f_{2}$ from Turkey, and $f_{3}$ from Algeria with the corresponding costs $c\left(x_{1} f_{1}\right)=16, c\left(x_{1} f_{2}\right)=10$, $c\left(x_{1}, f_{3}\right)=12$ thousand Euro.

It is evident that in the conditions before the outbreak of the COVID-19 crisis, the suppliers $f_{1}$ from Russia and $f_{3}$ from Algeria would not be engaged for carrying out logistic activities in the first phase of the logistic chain due to high costs. However, in the conditions of the COVID-19 crisis, the supplier $f_{3}$ from Algeria would be engaged as they provide for the work of the COVID-free supply chain irrespective of the costs being higher in this case (12 instead of 10 thousand Euro).

By doing so, based on the data from Table 1, eleven (11) potential supply chain participants are eliminated before and sixteen (16) after the COVID-19 crisis, and the appropriate logistic networks for solving the defined problem are given in Figures 4 and 5 .

Based on Figures 4 and 5, a far smaller number of qualified supply chain participants is evident in the conditions of the COVID-19 crisis whereby the possibility to run business normally is significantly decreased. 


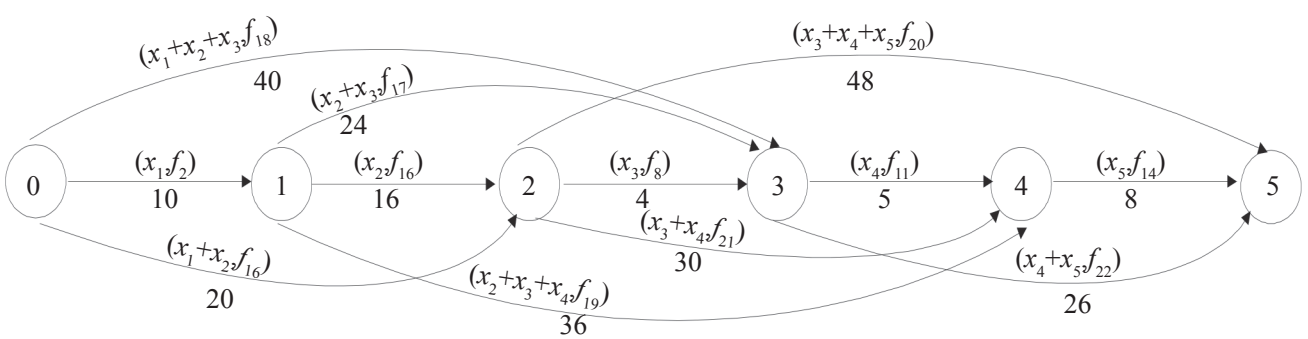

Figure 4-Logistic network of potential qualified global supply chain participants before the COVID-19 crisis

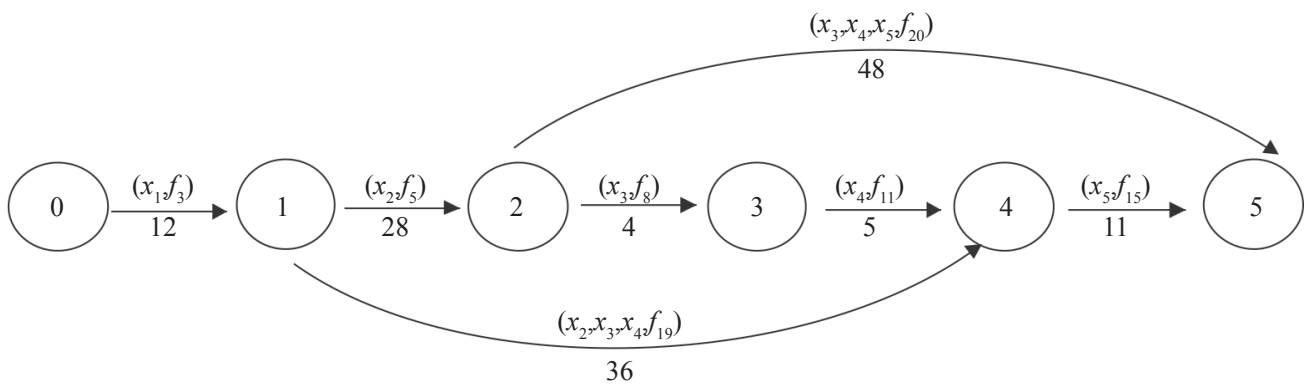

Figure 5-Logistic network of potential qualified global supply chain participants in the conditions of the COVID-19 crisis

A logistic chain phase is entered, as well as potential participants for carrying out a certain activity within the global logistic chain, above every branch of the logistic network (cf. Figures 4 and 5), and the costs for carrying out a certain phase within the logistic chain are entered under the branches of the logistic network. By applying the dynamic programming method for defining the shortest way in the network, i.e., by applying the recursive expression, the following is obtained:

\section{Before the COVID-19 crisis}

$f(0)=0$ i $f(1)=10$, and then

$f(2)=\min \left\{\begin{array}{l}f(0)+c\left(x_{1}+x_{2}, f_{16}\right)=0+20 \\ f(1)+c\left(x_{2}, f_{6}\right)=10+16=26\end{array}\right\}=20$

$f(3)=\min \left\{\begin{array}{l}f(0)+c\left(x_{1}+x_{2}, f_{16}\right)=0+40=40 \\ f(1)+c\left(x_{2}, f_{6}\right)=10+24=34 \\ f(2)+c\left(x_{3}, f_{18}\right)=20+4=24\end{array}\right\}=24$

$f(4)=\min \left\{\begin{array}{l}f(0)+\infty=0+\infty=\infty \\ f(1)+c\left(x_{2}+x_{3}+x_{4}, f_{19}\right)=10+36=46 \\ f(2)+c\left(x_{3}+x_{4}, f_{21}\right)=20+30=50 \\ f(3)+c\left(x_{4}, f_{11}\right)=24+5=29\end{array}\right\}=29$

and finally

$f(5)=\min \left\{\begin{array}{l}f(0)+\infty=0+\infty=\infty \\ f(1)+\infty=5+\infty=\infty \\ f(2)+c\left(x_{3}+x_{4}+x_{5}, f_{20}\right)=20+48=68 \\ f(3)+c\left(x_{4}+x_{5}, f_{22}\right)=24+26=50 \\ f(4)+c\left(x_{5}, f_{14}\right)=29+8=37\end{array}\right\}=37$ which means that before the COVID-19 crisis the length of the shortest way $p^{*}$, i.e., the minimum value of the function of the target $z^{*}=d\left(p^{*}\right)=37$, in which case $p^{*}=(0,2,3,4,5)$.

\section{During the COVID-19 crisis}

$f(0)=0$ i $f(1)=12$, and then

$f(2)=\min \left\{f(1)+c\left(x_{2}, f_{5}\right)=12+28\right\}=40$

$f(3)=\min \left\{f(2)+c\left(x_{3}, f_{8}\right)=40+4\right\}=44$

$f(4)=\min \left\{\begin{array}{l}f(1)+c\left(x_{2}+x_{3}+x_{4}, f_{19}\right)=12+36=48 \\ f(3)+c\left(x_{4}, f_{11}\right)=44+5=49\end{array}\right\}=48$

and finally

$f(5)=\min \left\{\begin{array}{l}f(2)+c\left(x_{3}+x_{4},+x_{5}, f_{20}\right)=40+48=88 \\ f(4)+c\left(x_{5}, f_{15}\right)=48+11=59\end{array}\right\}=59$

During the COVID-19 crisis, the length of the shortest way $p^{*}$, i.e., the minimum value of the function of the target $z^{*}=d\left(p^{*}\right)=59$, in which case $p^{*}=(0,1,4,5)$.

The optimal solution corresponding to the way before the COVID-19 crisis means that participant $f_{16}$ will be engaged in the global supply chain in the first and second execution phase, participant $f_{8}$ in the third phase, participant $f_{11}$ will be engaged in the fourth phase within the global supply chain, and participant $f_{14}$ in the last phase. These active participants form the optimal global supply chain that will provide the execution of the global undertaking at minimal costs in the amount of $€ 37,000$. During 
the COVID-19 crisis, participant $f_{3}$ will make up the optimal global supply chain in the first phase, participant $f_{19}$ in the second, third and fourth phase, and participant $f_{15}$ in the last phase. This means that it will lead to the shortening of the supply chain.

The fact that the most unfavorably formed global supply chain in the conditions before the COVID-19 crisis would incur costs in the amount of $€ 74,000$ underpins the importance of optimizing the potential qualified stakeholders of the global supply chain. Such a solution is obtained when the function is solved at the maximum, meaning the result is $(0,1,2,5)$. The global supply chain thus formed would be made up of stakeholders $f_{1}, f_{6}$ and $f_{20}$. The supply chain formed in the conditions of the COVID-19 crisis is the most inefficient in terms of costs, by $59.46 \%$ when compared with the optimal global supply chain formed before the outbreak of the COVID-19 crisis. Nevertheless, even during the COVID-19 crisis, the global supply chain formed in this way would incur less costs by as much as $25.42 \%$ when compared to the most unfavorably formed global supply chain before the COVID-19 crisis. The obtained optimal solution in the circumstances of the COVID-19 crisis is as much as $49,15 \%$ more favorable when compared to the most unfavorably formed global supply chain in the circumstances of the COVID-19 crisis $(0,1,2,5)-$ $€ 88,000$.

\section{CONCLUSION}

The COVID-19 crisis pointed at the vulnerability of the global economy and relations within global supply chains. The selection of the optimal number of supply chain participants in the circumstances of the COVID-19 crisis has imposed as an optimality criterion the possibility for participants to ensure the safety of a logistic process flow in all its phases from the point of delivery of raw materials to the point of delivery of products to end users. Safety as an optimality criterion results in a significantly smaller number of potential supply chain participants and bigger business costs. Increased supply chain business costs and bigger prices of delivered products are not necessarily followed by higher quality, which results in advocating protectionist measures and reviving non-competitive domestic production.

In the circumstances of the COVID-19 crisis, supply chain business costs may be even higher than the costs of the most unfavorably formed supply chains before the COVID-19 crisis. In the presented example, the costs of a non-optimized supply chain in the circumstances of the COVID-19 crisis are higher by $25,71 \%$ than the costs of the most unfavorably formed supply chain before the COVID-19 crisis, and even by $137,83 \%$ when compared to the costs of the optimally formed supply chain before the COVID-19 crisis.

The obtained results point to the conclusion that the COVID-19 crisis negatively affected all supply chain participants. The crisis of every participant within the supply chain has direct negative consequences on the supply chain and the economy as a whole. Negative consequences depend on the supply chain size, the number of potential participants, and the degree of exposure to global business. Accordingly, supply chain optimization in the circumstances of the COVID-19 crisis gains in importance even more.

DRAGO PUPAVAC, Ph.D. ${ }^{1}$

E-mail: drago.pupavac@veleri.hr

ROBERT MARŠANIĆ, Ph.D. ${ }^{2}$

E-mail: robert.marsanic1@gmail.com

LJUDEVIT KRPAN, Ph.D. ${ }^{3}$

E-mail: ljudevit.krpan@pgz.hr

${ }^{1}$ Veleučilište u Rijeci

Vukovarska 58, 51000 Rijeka, Hrvatska

2 Županijska uprava za ceste Primorsko-goranske županije Nikole Tesle 9, 51000 Rijeka, Hrvatska

3 Primorsko-goranska županija

Upravni odjel za regionalni razvoj, infrastrukturu i upravljanje projektima

Adamićeva 10, 51000 Rijeka, Hrvatska

\section{OPTIMIZACIJA COVID-19 SLOBODNIH OPSKRBNIH LANACA}

\section{SAŽETAK}

Temeljni cilj ovoga rada jest istražiti važnost optimizacije opskrbnih lanaca u uvjetima COVID-19 krize. Predmet istraživanja jest optimalni izbor aktivnih sudionika opskrbnog lanca prije i za vrijeme COVID-19 krize. Polazna hipoteza ovoga rada jest da se metodom dinamičkog programiranja mogu formirati optimalni COVID-19 slobodni opskrbni lanci čiji će troškovi biti veći od onih kada ovo ograničenje ne bi postojalo, ali ipak značajno niži od onih koji bi se formirali u uvjetima zanemarivanja principa optimalnosti pri odabiru sudionika opskrbnog lanca. Rezultati istraživanja u ovoj znanstvenoj raspravi temelje se na metodama analize i sinteze, komparativnoj metodi i metodi dinamičkog programiranja. Glavni nalaz ovoga rada upućuje na zaključak da je COVID-19 kriza utjecala na sigurnost poslovanja opskrbnih lanaca, smanjivanje broja potencijalnih sudionika u opskrbnim lancima i povećanje troškova poslovanja formiranih opskrbnih lanaca u novim uvjetima. 


\section{KLJUČNE RIJEČI}

opskrbni lanci; COVID-19; dinamičko programiranje; optimizacija.

\section{REFERENCES}

[1] World Health Organization. Available from: https:// covid19.who.int/ [Accessed 23rd May 2020].

[2] The April Monthly Briefing of the World Economic Situation and Prospects. Available from: https://www.un.org/ development/desa/dpad/publication/world-economic-situation-and-prospects-april-2020-briefing-no-136/ [Accessed 9th May 2020].

[3] Maliszewska M, Mattoo A, van der Mensbrugghe D. The Potential Impact of COVID-19 on GDP and Trade: A Preliminary Assessment. World Bank, Washington, DC. Policy Research Working Paper No. 9211, 2020. Available from: https://openknowledge.worldbank.org/handle/10986/33605 [Accessed 25th May 2020].

[4] Silvestre C, editor. The UniCredit Economics Chartbook. UniCredit Bank Milan; 2020. Available from: https://www.research.unicredit.eu/DocsKey/economics_docs_2020_176448.ashx?EXT=pdf\&KEY=C814QI31EjqIm_1zIJDBJFQWHqiVh6iWv-rRmfm0wl$\mathrm{w}=\& \mathrm{~T}=1[$ Accessed 15th May 2020].

[5] Thomas M. Croatia's economy expected to fall by 9.4 percent this year in COVID-19 driven recession. The Dubrovnik Times. 30 April 2020. Available from: https:// www.thedubrovniktimes.com/news/croatia/item/8877croatia-s-economy-expected-to-fall-by-9-4-percent-thisyear-in-covid-19-driven-recession [Accessed 2nd May 2020].

[6] Xinhua Net. Global economy could shrink by 1 pct in 2020 due to COVID-19 pandemic: UN. Available from: http:// www.xinhuanet.com/english/2020-04/02/c_138939242. htm [Accessed 4th April 2020].

[7] Deloitte. COVID-19: Managing supply chain risk and disruption Coronavirus highlights the need to transform traditional supply chain models. Available from: www. deloitte.ca [Accessed 4th May 2020].

[8] Bellman R. The Theory of Dynamic Programming. Santa Monica, California: The Rand Corporation; 1954. Available from: http://smo.sogang.ac.kr/doc/bellman.pdf. [Accessed 5th February 2020].

[9] Backović M, Vuleta J. Ekonomsko matematički metodi $i$ modeli. Drugo izdanje. Beograd: Ekonomski fakultet u Beogradu; 2002. Serbian.

[10] Dominguez R, Cannella S, Framinan MJ. The impact of the supply chain structure on bullwhip effect. Applied Mathematical Modelling. 2015;39(23-24): 7309-7325.

[11] Wright D, Yuan X. Mitigating the bullwhip effect by ordering policies and forecasting methods. International Journal of Production Economics. 2008;113(2): 587-597.

[12] Samuelson P, Nordhaus W. Economics. Nineteenth Edition. New York: McGraw Hill; 2010.

[13] Matinrada N, Roghaniana E, Rasib Z. Supply chain network optimization: A review of classification, models, solution techniques and future research. Uncertain Supply Chain Management. 2013;1(1): 1-24.

[14] Chopra S, Meindl P. Supply chain management: Strategy, planning and operation. $6^{\text {th }}$ editon. Edinburgh: Pearson Education Limited; 2016.

[15] Shukla SK, Tiwari MK, Wan H-D, Shankar R. Optimization of the supply chain network: Simulation, Taguchi, and Psychoclonal algorithm embedded approach. Computers \& Industrial Engineering. 2010;58(1): 29-39.

[16] Ding H, Benyoucef L, Xie X. Stochastic multi-objective production-distribution network design using simulation-based optimization. International Journal of Production Research. 2009;47(2): 479-505. 